Case Reports
in Dermatology

\title{
Erythema Ab Igne with Histological Features of Keratosis Lichenoides Chronica
}

\author{
Asja Prohic ${ }^{a} \quad$ Selma Poparic ${ }^{b} \quad$ Adem Cemerlic $^{c} \quad$ Aida Kapetanovic $^{d}$ \\ aDepartment of Dermatovenerology, Sarajevo Medical School, University of Sarajevo \\ School of Science and Technology, Sarajevo, Bosnia and Herzegovina; bepartment of \\ Dermatovenerology, Medical Centre Travnik, Travnik, Bosnia and Herzegovina; 'Faculty of \\ Medicine, University of Sarajevo, Sarajevo, Bosnia and Herzegovina; dDepartment of \\ Pathology, Clinical Center University of Sarajevo, Sarajevo, Bosnia and Herzegovina
}

\section{Keywords}

Erythema ab igne $\cdot$ Keratosis lichenoides chronica $\cdot$ Heat

\begin{abstract}
Erythema ab igne (EAI) is a localized, hyperpigmented and reticulated dermatosis at sites of chronic heat exposure. Within longstanding skin lesions of EAl, hyperkeratotic lesions may emerge and can potentially transform into pre-malignant or malignant skin lesions. A 55-yearold woman presented for the evaluation of multiple hyperkeratotic lesions along with a reticular patterned hyperpigmentation on her right knee, an area that had repeated and prolonged exposure to a heat source over a period of several months. Based on her clinical history and the physical examination of her lesions, she was diagnosed as having a hyperkeratotic form of EAI. A skin biopsy was performed to rule out malignant alteration, but the histopathological findings were supportive of keratosis lichenoides chronica.

(c) 2021 The Author(s)

Published by S. Karger AG, Basel
\end{abstract}

\section{Introduction}

Erythema ab igne (EAI) is an uncommon cutaneous condition characterized by localized areas of reticulate hyperpigmentation, epidermal atrophy, and at times, telangiectasias and 


\section{Case Reports in Dermatology}

Case Rep Dermatol 2021;13:184-189

DOI: $10.1159 / 000515259$

(c) 2021 The Author(s). Published by S. Karger AG, Basel www.karger.com/cde

Prohic et al.: Erythema Ab Igne Mimicking Keratosis Lichenoides Chronica

subepidermal bullae [1,2]. Changes in the skin typically occur from repeated exposure to direct heat or infrared radiation and develop over the course of weeks to years at temperatures that are insufficient to cause burns [3].

Although EAI is benign cutaneous condition, the most important long-term risk is the development of non-melanoma skin cancers, primarily squamous cell carcinoma [4] and, in rare cases, cutaneous lymphoma [5], as well as basal cell carcinoma [6]. Malignant alteration may be indicated by the presence of precancerous lesions, such as ulcerations [3] or hyperkeratosis $[7,8]$.

EAI demonstrates a wide array of histopathological findings, but only one clinical case of EAI with histological features of keratosis lichenoides chronica (KLC) has been described so far [9].

KLC is a rare dermatosis clinically characterized by linear or reticular hyperkeratotic papules and plaques on the trunk and extremities. The pathogenesis of the disease is unclear, but rare cases can be caused by heat exposure, closely resembling EAI [10].

We report a case of a female patient who presented with a hyperkeratotic form of EAI but with histopathological findings consistent with KLC.

\section{Case Report}

A 55-year-old woman presented with a reticular patterned hyperpigmentation along with hyperkeratotic papules and plaques on her right knee (Fig. 1).

As she described, it initially presented as a very pale lesion, but progressively changed to a more brownish-purple discoloration. Over time, the skin surface became rough upon touch.

Past medical history included osteoarthritis of the right knee, with joint pain and stiffness, most noticeable upon awakening. She had been using an electric heating pad repeatedly for several months to alleviate the pain, and often forgot to turn it off at night and would sleep with it in place.

The diagnosis of EAI was made based on the patient's clinical history, and the distribution and contour of the skin lesions. A punch biopsy of a keratotic papule was performed to rule out malignancy; histopathological examination showed lichenoid interface dermatitis with apoptotic keratinocytes and necrosis, and vacuolar degeneration of the basal layer. In addition, hypergranulosis and orthohyperkeratosis, dyskeratotic cells, and mild atypia of basal keratinocytes were noted. Dilated blood vessels with inflammatory cells were found in the papillary dermis (Fig. 2a, b).

\section{Discussion}

Historically, EAI has been associated with stove or open fire exposures [2]. Nowadays, it is more commonly seen after chronic use of heating pads or blankets, heated car seats, space heaters and, more recently, laptops [11]. These technologically novel heating devices emit low levels of infrared radiation, perceived as heat, which is thought to cause damage to superficial blood vessels, resulting in hemosiderin accumulation and subsequent hyperpigmentation [7].

Skin lesions typically occur on the anterior lower legs or the trunk but may be confined to the face and arms especially in chefs and cooks who work over an open fire [2,12]. Early lesions commonly present as transient, blanchable erythema; however, over time, and with

\section{Karger'=}




\section{Case Reports in Dermatology}

Case Rep Dermatol 2021;13:184-189

DOI: $10.1159 / 000515259$

(c) 2021 The Author(s). Published by S. Karger AG, Basel www.karger.com/cde

Prohic et al.: Erythema Ab Igne Mimicking Keratosis Lichenoides Chronica

prolonged heat exposure, the involved area evolves into a nonblanchable reticulated hyperpigmentation that may be associated with superficial atrophy and telangiectasias. Later-stage lesions may present as blistering with the consequent formation of ulcerations, or as hyperkeratotic skin lesions [2].

Histopathological findings usually mimic actinically damaged skin, demonstrating epidermal atrophy, telangiectasias, keratinocyte atypia, and hemosiderin accumulation in early lesions, while focal hyperkeratosis, dyskeratosis and altered dermal elastic fibers may be observed in later stages $[11,12]$. Rare cases with associated histopathological findings of lichen planus (LP) have been described in the available literature [13, 14]. However, the wedgeshaped hypergranulosis and the absence of parakeratosis in LP help to distinguish these two entities.

Because of a wide array of histopathological findings, skin biopsy is frequently performed to exclude other differential diagnoses such as livedo reticularis and cutis marmorata or to rule out malignant change $[1,2]$.

Similar to our case, a recently published report described a patient with skin lesions typical of EAI that occurred after chronic use of heating pads, but with histopathology corresponding to KLC [9]. The disease was first described by Kaposi in the late 19th century and is still the subject of debate as to whether it is a separate entity or a clinical variant of LP [15].

Compared to EAI, the histopathology of KCL shows features of lichenoid interface dermatitis with necrotic keratinocytes and vacuolar degeneration of the basal layer. Irregular acanthosis, hyperkeratosis, parakeratosis, and hypergranulosis of the outer epidermis, chronic inflammatory infiltrate in the papillary dermis, and vascular dilatation may be present [16].

However, the absence of other skin symptoms, primarily seborrheic dermatitis-like facial eruption and nail changes, but also a history of prolonged heat exposure, enabled us to o rule out KLC.

Only one report of KLC, probably activated by prolonged exposure to infrared radiation, indicated the role of heat as a trigger for dermatosis. Because the lesion site was confined to exposed areas, the authors suggested the role of the Koebner reaction in the development of skin lesions, alike to LP [10].

EAI is usually an asymptomatic condition and, in most cases, the rash resolves with removal of the heat source. Some chronic cases may require topical therapies such as tretinoin and hydroquinone to avoid persistent hyperpigmentation or 5 -fluorouracil, imiquimod, and photodynamic therapy if there is suspicion of dysplastic changes $[1,9]$.

\section{Conclusion}

EAI can exhibit a spectrum of clinical and histopathological features, including a fixed, reticulated pattern of hyperpigmentation, which can progress to hyperkeratosis, and lichenoid interface dermatitis corresponding to KLC. However, a patient history of chronic heat exposure, and the distribution and location of lesions are all suggestive of the diagnosis of EAI.

\section{Statement of Ethics}

This research work was conducted in accordance with the Declaration of Helsinki. The subject of the case has given her written informed consent to publish this case.

\section{Karger'=}




\section{Case Reports in Dermatology}

\section{Conflict of Interest Statement}

There are no conflicts of interest.

\section{Funding Sources}

None.

\section{Author Contributions}

A.P. and S.P. drafted the manuscript, and A.P. revised it critically for important intellectual content and gave final approval of the version to be published, A.C. and A.K. contributed to the preparation of the manuscript.

\section{References}

1 Milchak M, Smucker J, Chung CG, Seiverling EV. Erythema Ab Igne due to Heating Pad Use: A Case Report and Review of Clinical Presentation, Prevention, and Complications. Case Rep Med. 2016;2016:1862480.

2 Forouzan P, Riahi RR, Cohen PR. Heater-Associated Erythema Ab Igne: Case Report and Review of ThermalRelated Skin Conditions. Cureus. 2020 May;12(5):e8057.

3 Turan E, Yeșilova Y, Uçmak D, Celik Öİ. Thermal pillow: an unusual causative agent of erythema ab igne. Turk J Pediatr. 2013 Nov-Dec;55(6):648-50.

4 Wharton JB, Sheehan DJ, Lesher JL Jr. Squamous cell carcinoma in situ arising in the setting of erythema ab igne. J Drugs Dermatol. 2008 May;7(5):488-9.

5 Wharton J, Roffwarg D, Miller J, Sheehan DJ. Cutaneous marginal zone lymphoma arising in the setting of erythema ab igne. J Am Acad Dermatol. 2010 Jun;62(6):1080-1.

6 Daneshvar E, Seraji S, Kamyab-Hesari K, Ehsani AH, Hanifnia AR, Razavi Z. Basal cell carcinoma associated with erythema ab igne. Dermatol Online J. 2020;26(4):13030/qt3kz985b4.

7 Sigmon JR, Cantrell J, Teague D, Sangueza O, Sheehan DJ. Poorly differentiated carcinoma arising in the setting of erythema ab igne. Am J Dermatopathol. 2013 Aug;35(6):676-8.

8 Sood A, Sharma S, Khanna N. Cutaneous horn and thermal keratosis in erythema AB igne. Indian J Dermatol Venereol Leprol. 2002 Jul-Aug;68(4):237-8.

9 Wells A, Desai A, Rudnick EW, Motaparthi K. Erythema ab igne with features resembling keratosis lichenoides chronica. J Cutan Pathol. 2021 Jan;48(1):151-3.

10 Vernassiere C, Reichert Penetrat S, Martin S, Barbaud A, Schmutz JL. [Keratosis lichenoides chronica and prolonged exposure to infrared radiation]. Ann Dermatol Venereol. 2004 Jun-Jul;131(6-7 Pt 1):575-7.

11 Riahi RR, Cohen PR. Laptop-induced erythema ab igne: report and review of literature. Dermatol Online J. 2012 Jun;18(6):5.

12 Arrington JH 3rd, Lockman DS. Thermal keratoses and squamous cell carcinoma in situ associated with erythema ab igne. Arch Dermatol. 1979 0ct;115(10):1226-8.

13 Little EG. Erythema ab Igne, or, alternatively, Lichen Planus. Proc R Soc Med. 1929 Jun;22(8):1013-4.

14 Horio T, Imamura S. Bullous lichen planus developed on erythema ab igne. J Dermatol. 1986 Jun;13(3):2037.

15 Jayaraman AG, Pomerantz D, Robinson-Bostom L. Keratosis lichenoides chronica mimicking verrucous secondary syphilis. J Am Acad Dermatol. 2003 Sep;49(3):511-3.

16 Pistoni F, Peroni A, Colato C, Schena D, Girolomoni G. Keratosis lichenoides chronica: case-based review of treatment options. J Dermatolog Treat. 2016 Aug;27(4):383-8. 


\section{Case Reports in Dermatology}

(c) 2021 The Author(s). Published by S. Karger AG, Basel www.karger.com/cde

Prohic et al.: Erythema Ab Igne Mimicking Keratosis Lichenoides Chronica

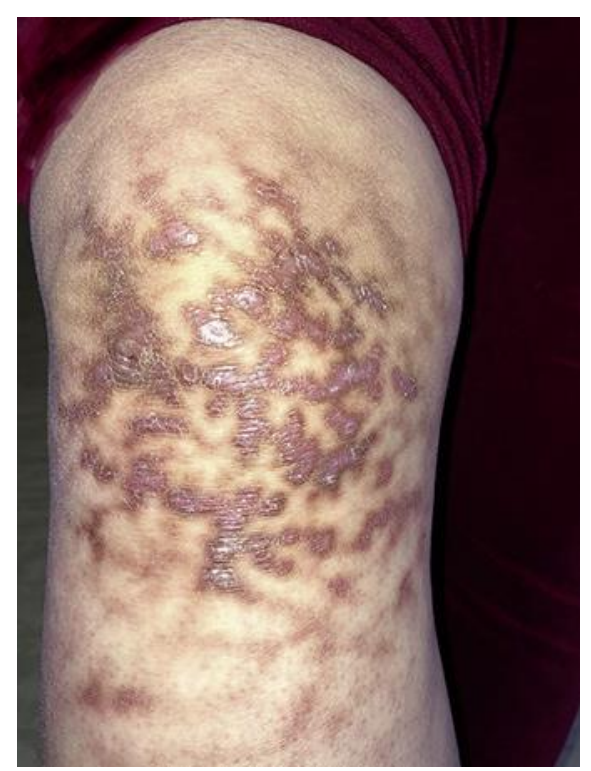

Fig. 1. Reticulated, reddish-brown pigmented patch with hyperkeratotic papules and small plaques on the right knee of a female patient. 


\section{Case Reports in Dermatology}

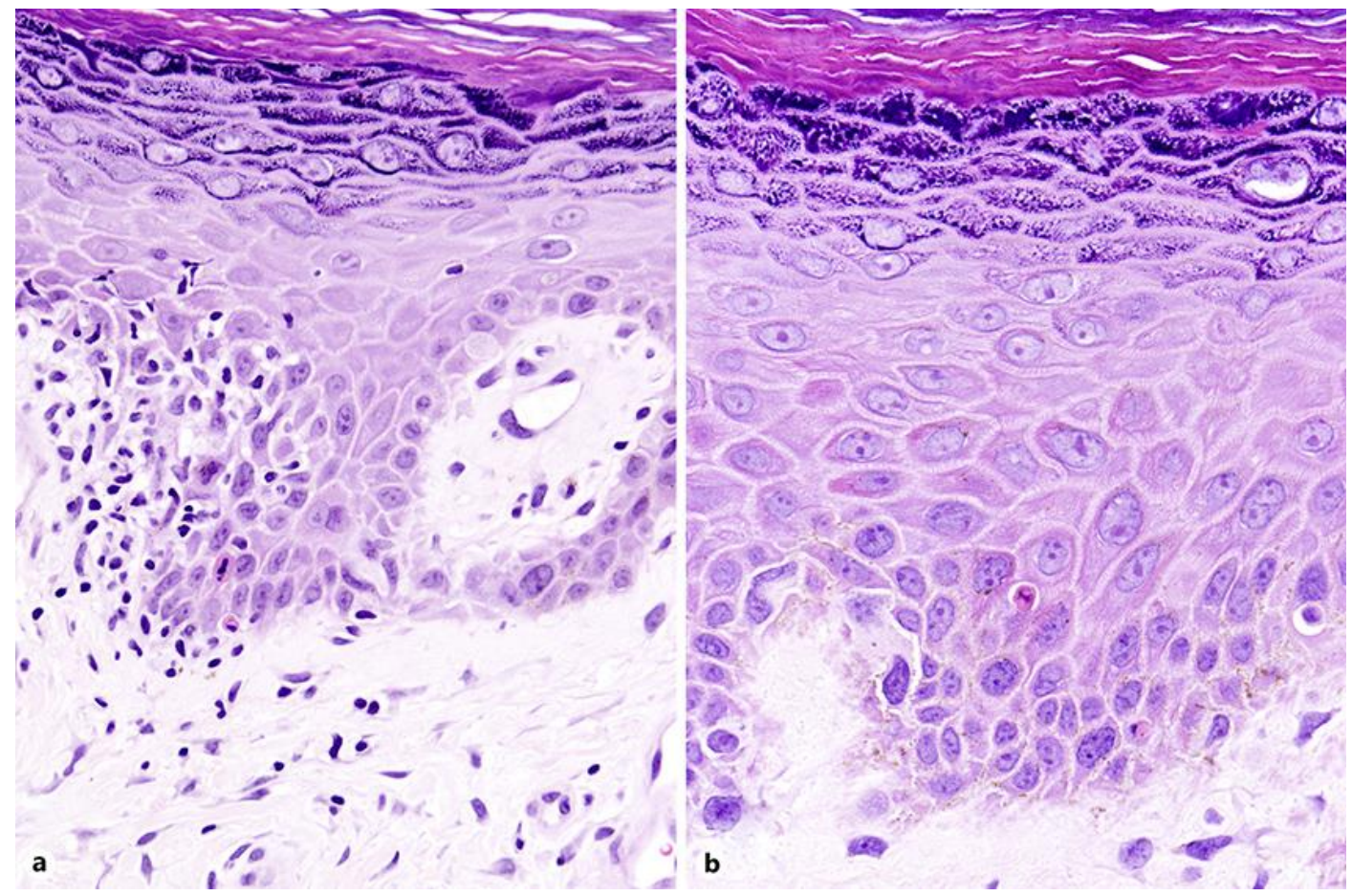

Fig. 2. Histopathology of EAI. Epidermis showing acanthosis, mild atypia of basal cells, hypergranulosis and orthohyperkeratosis, rare dyskeratotic cells, pigment incontinence and vacuolar degeneration of the basal layer $(H \& E$, magnification $\times 10)(a)$, interface dermatitis, apoptotic keratinocytes, slightly dilated blood vessels with perivascular lymphocytic infiltration within the papillary dermis (H\&E, magnification $\times 20$ ) (b). 